\title{
大振幅水平載荷実験による群杭・地盤系の非線形挙動 \\ NON-LINEAR BEHAVIOR OF PILE GROUP-SOIL SYSTEM BASED ON HORIZONTAL LOADING TEST SUBJECT TO LARGE DISPLACEMENT
}

\author{
倉田高 志*, 柏 尚 稔**, 林 康 裕 ${ }^{* * *}$, 田村 修 次 $* * * *$, 吹田 啓一郎 $* * * * *$ \\ Takashi KURATA, Hisatoshi KASHIWA, Yasuhiro HAYASHI, \\ Shuji TAMURA and Keïchiro SUITA
}

\begin{abstract}
Nonlinear soil-structure interaction effects under strong ground motions should be considered in the seismic design. This paper presents the results of cyclic loading test for pile foundation in dry sand to investigate the nonlinear behavior of pile foundation in large displacement range. The experimental parameters are the number of piles, loading rate, relative density of soil and alignment of pile group. The major findings obtained from tests are summarized as follows: 1) the soil around piles deformed significantly even at small amplitude, 2) shear force-displacement relationship, resultantly secant stiffness and equivalent damping factor, at pile head shows significant nonlinearity even in very small displacement range, 3) shear force at pile head hold almost constant value after the soil get failed.
\end{abstract}

Keywords : Pile group, Horizontally cyclic loading test, Dry sand, Secant stiffness, Equivalent damping factor 群杭, 繰り返し水平載荷試験, 乾燥砂, 割線剛性, 等価減衰定数

\section{1.はじめに}

南海地震、東南海地震、東海地震をはじめとするプレート境界型 の巨大地震の発生が懸念されているが、その発生前後には各地で活 断層による内陸直下の地震が多発すると言われている。そのような 地震の代表例として、兵庫県南部地震、鳥取県西部地震、新潟県中 越地震などが挙げられるが、これらの震源域では設計用地震荷重を 大きく上回る高レベル地震動が観測された。この様な地震動が作用 した場合の建築物の地震時挙動を解明し、建築物の耐震設計に合理 的に反映させるためには、建築物と地盤間の強非線形相互作用効果 を適切に考慮することが不可欠である。よって、まずは実験データ を蓄積しながら現象を解明する必要があると考えられる。

群杭基磷と地盤間の強非線形相互作用効果を調べた既往の実験的 研究の中で、単調載荷で杭径以上の水平変位を杭頭に与えた実験と

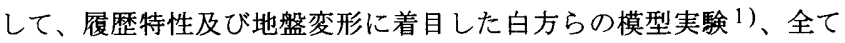
の杭について塑性ヒンジが発生し、かつ地盤も塑性化に至るまでの 挙動を考察した富永らの模型実験 2 ） が挙げられる。杭径以内の変 位ではあるが、銅管杭の杭頭に塑性ヒンジが発生するまで繰返し載 荷した青砥らの実大実験 ${ }^{3}$ )がある。また、杭が弾性範囲内での実 験ではあるが、群杭中の杭頭せん断力の分担と地盤変状の経過に着

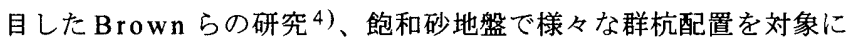
地盤反力 - 杭变位関係、杭頭バネ定数、減哀定数について比較検討 をした鈴木らの研究 5)や、動的載荷による影響をみた小林ら 6)、大

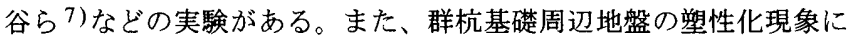
着目し、理論式を構築し実大杭頭単調実験と比較検証を行った山肩 らの研究 8),9)もある。

これらの研究では、一部の単調載荷実験を除き、動的載荷も含め て杭径以上の大振幅で繰返し載荷した実験例は見あたらず、また、 杭配置に対して載荷方向を 45 度変えた繰返し載荷の実験例につい ては皆無である。そこで本研究は、使用する杭の断面形状・長さを 一定として、杭配置、載荷速度(動的・静的)、地盤密度、載荷方 向などをパラメータとして、群杭の大振幅まで漸増絽返し載荷実験 を系統的に実施した。本論文では、群杭基礎に大振幅水平変位を与 えて、群杭中の各杭が弾性限界を超え、塑性ヒンジを形成した後、 さらに変形を加え、杭径以上の変位まで載荷する一連の過程におけ る(1)地盤の変状、(2)杭頭荷重一杭頭変位関係、(3)割線剛性・履歴減 衰定数、(4)極限状態での地盤と杭の挙動を杭・地盤系の強非線形性 に着目し、実験結果の報告を行う。

\footnotetext{
$*$ 京都大学大学院工学研究科建築学尃攻 修士課程

** 京都大学大学院工学研究科建築学専攻 博士課程·工修

${ }^{* * *}$ 京都大学大学院工学研究科建築学尃攻 教授 $\cdot$ 工博

**** 京都大学防災研究所 准教授・工博

***** 京都大学大学院工学研究科建築学専攻 准教授・工博
}

Graduate Student, Dept. of Architecture and Architectural Eng., Kyoto Univ. Graduate Student, Dept. of Architecture and Architectural Eng., Kyoto Univ., M. Eng.

Prof., Dept. of Architecture and Architectural Eng., Kyoto Univ., Dr. Eng. Assoc. Prof., Disaster Prevention Research Institute, Kyoto Univ., Dr. Eng.

Assoc. Prof., Dept. of Architecture and Architectural Eng., Kyoto Univ., Dr. Eng. 


\section{2. 実験方法}

杭・地盤模型と実験装置の全体を図 1 に示す。固定土槽は高さ $1.0 \mathrm{~m}$ 、 幅 $1.2 \mathrm{~m}$ 、奥行き $3.0 \mathrm{~m}$ である。図中に示すように、杭試験体の杭 頭部分は、載荷フレームに固定度の高いフーチングを介し、高力ボ ルト接合されている。フーチングと杭頭部分との接合の詳細は図 2 のようになっており、杭頭部分は十分な固定度を持って接合されて いる。杭先端は土槽底より離れており自由である。栽荷フレームは 摩擦の小さいガイドローラーで上下面外の移動を拘束するよう支持 され、一端をアクチュエータに連結して水平 1 方向だけ載荷される 機構となっている。

実験地盤は材料物性が明らかな乾燥した豊浦砂を用い、深さ $950 \mathrm{~mm}$ の地盤を作成した。各試験体で地盤と杭の挙動を精度良く比較する ため、実験ごとの地盤の条件が同一になるようにする必要がある。 よって本実験では厚さ $100 \mathrm{~mm}$ の層を 9 層、厚さ $50 \mathrm{~mm}$ の層を 1 層、 計 10 層に分け砂を積み重ねる。その際、各層で所定の相対密度と なるように砂重量を決定し、層厚が目標值となるように管理しなが ら締め固めた。

杭の諸元を表 1 に示す。杭試験体は $\phi 60.5 \times 8.0$ 、長さ $1000 \mathrm{~mm}$ の鋼管(STK400) を使用した。短柱圧縮試験の結果、鋼材の降伏 応力は $288 \mathrm{~N} / \mathrm{mm}^{2}$ であり、杭の断面形状から降伏モーメント $4.60 \mathrm{kN}$ ・ $\mathrm{m}$ 、全塑性モーメント $6.80 \mathrm{kN} \cdot \mathrm{m}$ を算出した。また、弹性域でか つ地盤に埋まっていない位置の歪を用いて、杭頭が全塑性そーメン
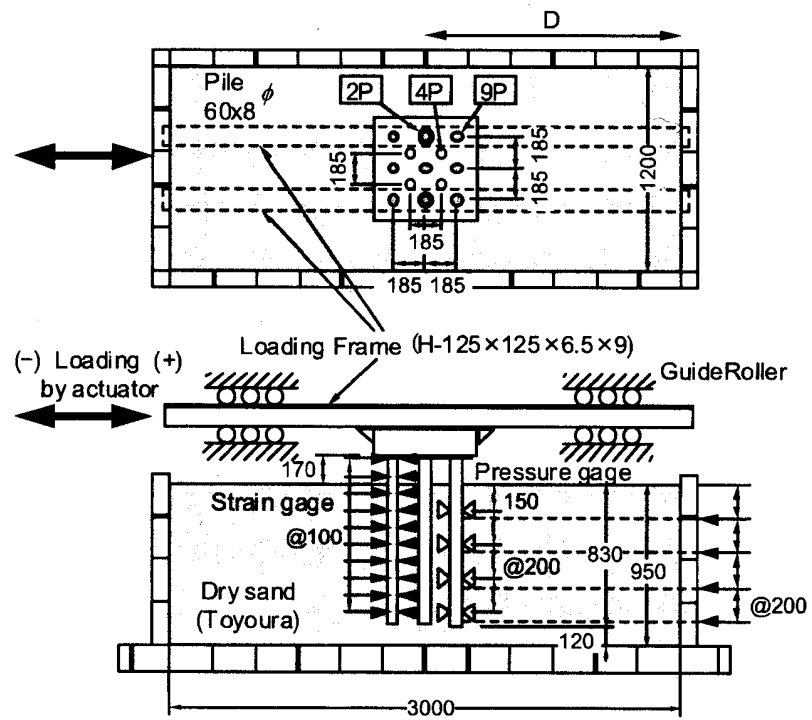

図 1 杭・地盤模型と実験装置 (単位: $\mathrm{mm}$ )
トに達しているか否かを判断した。

表 2 に 7 種類の実験の諸元を示す。杭本数の異なる実験として、 単杭を模して載荷直交方向に杭径の 6 倍の閒隔 $($ 杭中心間隔 $370 \mathrm{~mm}$ ) で 2 本ならべた $2 \mathrm{P}$ 、群杭を模して杭径の 3 倍の間隔(杭中心間隔 $185 \mathrm{~mm}$ )で $2 \times 2$ 本配置した $4 \mathrm{P} 、 3 \times 3$ 本配置した $9 \mathrm{P}$ の 3 種類を 設定した。また、4P を基準とし条件の異なる実験として、正弦波 で動的載荷した $4 \mathrm{P}-\mathrm{D}$ 、相対密度 $45 \%$ の地盤を設置した $4 \mathrm{P}-\mathrm{L}$ 、載 荷方向を $45^{\circ}$ 回転させた $4 \mathrm{P}-\mathrm{X}$ 、境界条件の影響を調べるため杭試 験体位置を $500 \mathrm{~mm}$ ずらし土槽壁面までの距離 $\mathrm{D}$ (図 1 に示す) を $2000 \mathrm{~mm}$ に変えた $4 \mathrm{P}-\mathrm{B}$ の 4 種類を設定した。各実験の相対密度は $2 \mathrm{P}$ が $63 \% 、 4 \mathrm{P}$ が $61 \% 、 9 \mathrm{P}$ が $62 \% 、 4 \mathrm{P}-\mathrm{D}$ が $62 \% 、 4 \mathrm{P}-\mathrm{L}$ が $45 \%$ 、 $4 \mathrm{P}-\mathrm{X}$ が $62 \% 、 4 \mathrm{P}-\mathrm{B}$ が $61 \%$ であった。なお、各実験の地盤の単位 体積重量は $4 \mathrm{P}-\mathrm{L}$ が $14.3 \mathrm{kN} / \mathrm{m}^{3}$ 、その他の実験ではいずれも $14.8 \mathrm{kN} /$ $\mathrm{m}^{3}$ であった。載荷プログラムについて、静的載荷をした実験では $\pm 1,2,4,6,8,10,12,15,18,24,30,45,60 \mathrm{~mm}$ の順に漸増振幅 で 2 サイクルずつ繰り返した後、 $120,180 \mathrm{~mm}$ の振幅で 1 サイク ルずつ漸増載荷した。ただし、単杭の実験 $(2 \mathrm{P})$ のみ $24 \mathrm{~mm}$ までの

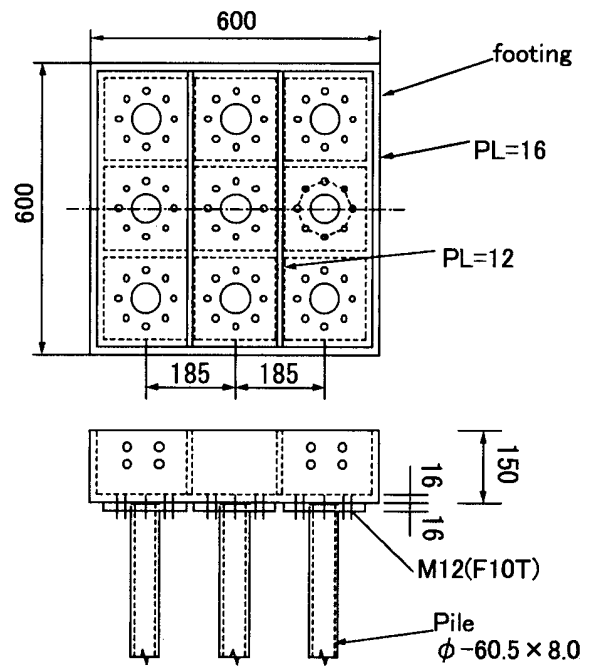

図 2 フーチングと杭頭部分の接合方法

\begin{tabular}{|c|l|}
\multicolumn{2}{c|}{ 表 1 杭の諸元 } \\
\hline 杭長 & $l=1000 \mathrm{~mm}$ \\
\hline 杭径(実測値) & $\phi=60.23 \mathrm{~mm}$ \\
\hline 厚さ(実測値) & $t=8.86 \mathrm{~mm}$ \\
\hline 降伏応カ & $\sigma_{v}=288 \mathrm{~N} / \mathrm{mm}^{2}$ \\
\hline 降伏モーメント & $M_{y}=4.60 \mathrm{kN} \cdot \mathrm{m}$ \\
\hline 全塑性モーメント & $M_{p}=6.80 \mathrm{kN} \cdot \mathrm{m}$ \\
\hline
\end{tabular}

表 2 実験の諸元

\begin{tabular}{|c|c|c|c|c|c|c|c|}
\hline 実験 & $2 \mathrm{P}$ & $4 \mathrm{P}$ & $9 \mathrm{P}$ & 4P-D & $4 \mathrm{P}-\mathrm{L}$ & $4 \mathrm{P}-\mathrm{X}$ & 4P-B \\
\hline 杭本数 & 2本 & 4本 & 9本 & 4本 & 4本 & 4本 & 4本 \\
\hline 相対密度 & $63 \%$ & $61 \%$ & $62 \%$ & $62 \%$ & $45 \%$ & $62 \%$ & $61 \%$ \\
\hline 載荷速度 & 静的 & 静的 & 静的 & 動的 & 静的 & 静的 & 静的 \\
\hline 載荷方向 & $0^{\circ}$ & $0^{\circ}$ & $0^{\circ}$ & $0^{\circ}$ & $0^{\circ}$ & $45^{\circ}$ & $0^{\circ}$ \\
\hline 杭の位置 (D) & $1500 \mathrm{~mm}$ & $1500 \mathrm{~mm}$ & $1500 \mathrm{~mm}$ & $1500 \mathrm{~mm}$ & $1500 \mathrm{~mm}$ & $1500 \mathrm{~mm}$ & $2000 \mathrm{~mm}$ \\
\hline$\underset{\text { (Loading) }}{\stackrel{\text { 杭 の配 置 }}{\longrightarrow}}$ & $\underset{0}{\stackrel{5}{\longrightarrow}}$ & $\stackrel{\substack{\infty_{0}^{185} \\
\hdashline}}{\longrightarrow}$ & {$\left[\begin{array}{cccc}185 & 185 \\
0 & 0 & 0 \\
0 & - & 0 & 0 \\
0 & 0 & 0\end{array}\right.$} & $\stackrel{\infty}{\infty} \int_{0}^{18}$ & & $\underset{0}{18 / 0}$ & $\stackrel{\infty}{\infty}$ \\
\hline
\end{tabular}


繰返し載荷とした。静的実験の載荷速度は、最大 $0.5 \mathrm{~mm} / \mathrm{sec}$ に設 定した。動的載荷した実験(4P-D)では、静的試験と同様の載荷振 幅で正弦波を用いて載荷を行った。動的実験の載荷速度を静的実験 と差をつけるため、アクチュエータの性能上最速の速さで載荷した。 各振幅における加振周期は、振幅 $30 \mathrm{~mm}$ までは 0.5 秒で、その後は 振幅の増大に伴って周期を長くし、振幅 $180 \mathrm{~mm}$ では周期 2 秒で 載荷した。

荷重、変位、歪、圧力の計測は、アクチュエータと載荷フレーム の間に設置したロードセル、アクチュエータ内蔵の変位計、各杭に 取り付けた歪ゲージ、圧力計を用いて行った。杭に取り付けた歪ゲー ジと土圧計の配置を図 3 に示す。杭のセンサ一配置パターンは、歪 ゲージを $100 \mathrm{~mm}$ 間隔で貼付した A 1 、歪ゲージを $200 \mathrm{~mm}$ 間隔で貼 付した A2、土圧計を $200 \mathrm{~mm}$ 間隔で設置した B 1、センサーを設置 していないNの 4 種類とし、杭配置の対称性などを考慮して全体の センサー配置を決定している。また、杭の変形量を調べるため、4P$\mathrm{X}$ と 4P-B については杭の梁さ $200 \mathrm{~mm} 、 400 \mathrm{~mm} 、 600 \mathrm{~mm} 、 800 \mathrm{~mm}$ でそれぞれワイヤーを取り付け、土槽の妻面のピンホールを通して 外に出し、その先の変位計で水平変位を直接測った(図 1)。

\section{3. 地盤変状}

2P、4P、9P、4P-L、4P-X の実験で観測された地盤変状を図 4、 5、6、7、8に示す。図中に記した実線は各振幅の載荷終了時に おける地盤表面の形状を表し、平面図の点線は地盤のすべりによっ て現れた線状の痕跡を表す。また、すり鉢状の地盤変形が現れた杭 周囲の地盤 (以下、杭周囲地盤と呼ぶ) は振幅 $12 \mathrm{~mm}$ から $30 \mathrm{~mm}$ の 閒で、杭周囲地盤より外側の地盤 (以下、外周地盤と呼ぶ) は振幅 $60 \mathrm{~mm}$ 以上で、地盤変状の特徴が顕著に現れたので、それぞれ代 表的な様子を以下の写真に示す。すなわち、2P、4P の振幅 $12 \mathrm{~mm}$ 、 振幅 $24 \mathrm{~mm}$ 載荷時の地盤の様子を写真 $1 、 2 、 3 に 、 4 \mathrm{P}$ の載荷方向 に並ぶ杭の間の地盤に現れた変状線を写真 4 に、4P-X の振幅 $18 \mathrm{~mm}$ の載荷時の地盤の様子を写真 5 に、大振幅での杭周囲の地盤変状と して9P の振幅 $180 \mathrm{~mm}$ 載荷時の地盤の様子を写真 6 に、振幅 $180 \mathrm{~mm}$ 載荷時の $4 \mathrm{P} 、 4 \mathrm{P}-\mathrm{B}$ の外周地盤の様子を写真 7、8 に示す。

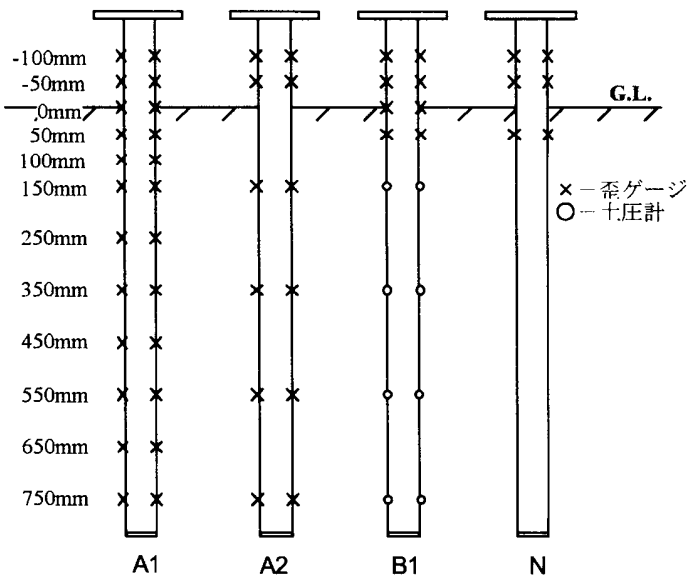

（a）各杭のセンサー配置パターン
2P の場合、載荷の初期では載荷方向の前面の地盤に目視で微か に分かる程度の低い盛り上がりが観察され、逆に後方では杭の移動 に伴ってできる地盤との間の隙間へ砂が崩れながら落下して斜面を 形成した。この斜面は載荷の繰返しに伴ってすり鉢状になり、振幅 $8 \mathrm{~mm}$ で顕著に観察されるようになった。以下、この杭周囲地盤の 変形状態をすり釷㭔ぶ。Brown らの研究4)でもこのすり鉢状の 地盤変状が観察されたと報告されている。また、外周地盤は広範囲 にわたり徐々に盛り上がった。その後、写真 1 の(a)、(b)で示すよ うに、振幅の増大に伴ってすり鉢の径と媣さが成長し、振幅 $24 \mathrm{~mm}$ で深さ $100 \mathrm{~mm}$ に達し、平面で見ると短径 $310 \mathrm{~mm}$ 、長径 $380 \mathrm{~mm}$ の 楕円の穴になった(図 4、写真 1)。

$4 \mathrm{P}$ の場合、載荷方向外側の杭周囲地盤は載荷正方向側・負方向 側それぞれに対し、大きなすり鉢のくぼみを一つずつ形成した。こ のすり鉢はそれぞれ載荷直交方向に並ぶ 2 本の杭を中心とするすり 鉢であった。載荷方向に並ぶ杭間の地盤はすり鉢状にならず、山形 の形状で振幅の増加に伴って徐々にその頂きの高さが低くなるのが 観察された(図 5)。また、外周地盤は $2 \mathrm{P}$ と同様に広範囲にわたり 徐々に盛り上がった。写真 2 の (a)、(b)で示すように、振幅の増大 に伴ってすり鉢の径と梁さが成長し、振幅 $18 \mathrm{~mm}$ を超えると、載荷 方向で挟まれる杭間の地盤は周囲との間にずれを生じ、杭径と同じ 間隔の 2 本の平行な地盤変状線( 以下、変状線と呼ぶ)が地表に現 れた(写真 4)。この変状線で囲まれる地盤は杭と一体となって移動 した。その後、振幅 $30 \mathrm{~mm}$ では杭間の砂が崩れ始め、振幅 $60 \mathrm{~mm}$ で 4 本の杭を中心に深さ $150 \mathrm{~mm}$ 、短径 $600 \mathrm{~mm}$ 、長径 $880 \mathrm{~mm}$ の大き なすり鉢に成長した。振幅 $60 \mathrm{~mm}$ を超えると外周地盤はさらに広範 囲にわたって隆起し、はっきりとした段差が現れた(写真 7)。

次に、4P と実験条件の異なる実験とで比較を行った結果につい て説明する。4P と境界条件の異なる 4P-B では、杭周囲地盤の地盤 変状について、4P との間に明確な違いはみられなかった。また、写 真 7、8 より振幅 $60 \mathrm{~mm}$ を超えて現れた外周地盤の段差の範囲を比 較してみると、杭から段差が出来る位置までの距離 B(4P-B につい ては土槽までの距離が広い側)に差はなかった。よって、杭周囲地 盤の地盤変状、外周地盤の段差の発生位置は土槽側面の抵抗によっ て大きく影響されないと推察される。動的載荷をした 4P-Dについ ても、杭周囲地盤の地盤変状・外周地盤の段差の範囲は $4 \mathrm{P}$ との間

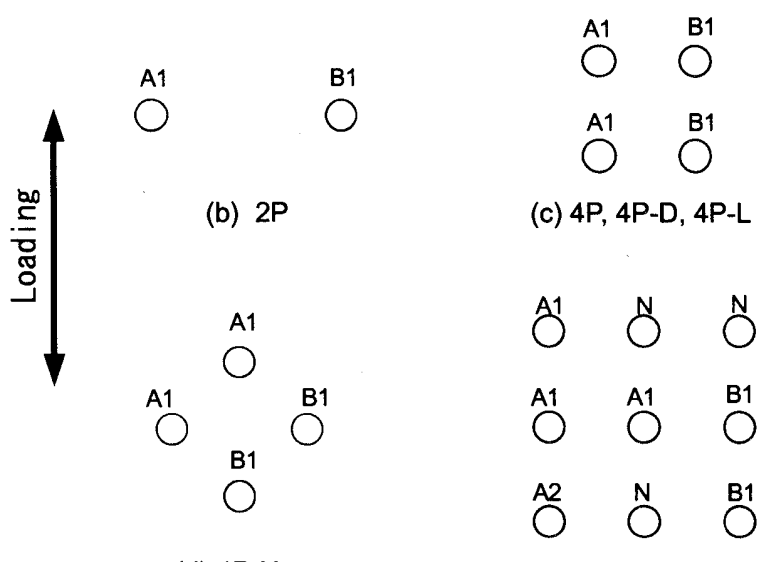

(d) $4 \mathrm{P}-\mathrm{X}$

(e) $9 \mathrm{P}$

図 3 センサー配置図 
に明確な違いが見られず、これらは載荷速度の影響をほとんど受け ないことが分かった。相対密度の小さい $4 \mathrm{P}-\mathrm{L}$ について、杭周囲地 盤にすり鉢を形成する地盤変状は $4 \mathrm{P}$ と共通するが、外周地盤は $4 \mathrm{P}$ と異なり全体的に沈下する挙動が観察された(図 7(a))。この外周 地盤の沈下は、ゆるい地盤が載荷に伴ってより密な地盤になるため に生じたと考えられる。4 5 度方向載荷した $4 \mathrm{P}-\mathrm{X}$ の地盤変状は、0 度方向載荷の $4 \mathrm{P}$ のように載荷正方向側・負方向側それぞれに、大 きなすり鉢を一つずつ形成するのではなく、群杭全体を囲む一つの 大きなすり鉢を形成し、各杭の周囲にも局所的なくぼみを形成した (図 8、写真 5)。載荷方向の杭間の地盤に 45 度方向に变状線が現 れ、変状線で囲まれる地盤は杭と一体となって移動した。振幅 $30 \mathrm{~mm}$ を超えると個別にできたすり鉢の大きさは拡大し、各杭の近傍に形 成した局所的なくぼみの大きさも拡大した。載荷条件を变えた実験 全てについて、4P と同様に振幅 $60 \mathrm{~mm}$ を超えると外周地盤にはっ きりとした段差が現れた。

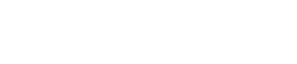

9P の場合も $4 \mathrm{P}$ とよく似ており、4P で見られた地盤変形の特徴 が同様に観察された。ただし、4P と同様にすり鉢が外周杭の周囲 にそれぞれ二つ形成されるが、9本のうち載荷方向の中間に位置す る 3 本の杭の周囲の地盤は 4P の杭間の地盤と比べて、崩れるのが 遅いという特徴が見られた(図 6、写真 3 )。振幅 $60 \mathrm{~mm}$ では二つの すり鉢が重なり、9 本の杭を中心とする哚さ $150 \mathrm{~mm}$ 、短径 $820 \mathrm{~mm}$ 、 長径 $1020 \mathrm{~mm}$ の大きな一つのすり鉢へと成長した。また、4P と同 様に外周地盤は広範囲にわたって隆起し、振幅 $60 \mathrm{~mm}$ を超えるとはっ きりとした段差が現れた。

実験終了後の杭の状況は写真 6 に例示するように、杭先端が中央 一奇る向きに残留変形が生じている。これは図 9 に示すように正負 交番繰返し載荷で常に前方杭に残留変形が生じた結果であり、その 理由は前方杭と後方杭のせん断力分担の非対称性によると考えられ る。

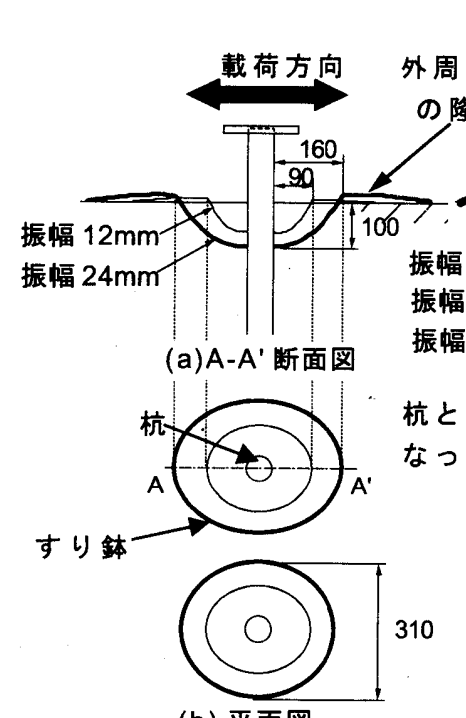

(b) 平面図

図 4 2P の地盤変状

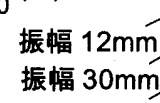
振幅 $60 \mathrm{~mm}$

変状線 


\section{4. 杭頭荷重 - 杭頭変位関係}

振幅 $24 \mathrm{~mm}$ までの $2 \mathrm{P} 、 4 \mathrm{P} 、 9 \mathrm{P}$ の杭頭荷重一杭頭変位関係を図 10 に示し、4P、9P、4P-D、4P-L、4P-X、4P-B の振幅 $180 \mathrm{~mm}$ までの杭頭荷重一杭頭変位関係を図 9 に示す。全ての実験で、杭 頭荷重一杭頭変位関係の履歴特性に後述のような同様の傾向が見ら れたので、2P、4P、9P についての結果を示す。また、各実験にお いて、正方向載荷の前方杭・もしくは中間杭の杭頭が全塑性状態に 至った「変位(振幅・サイクル数)」を図 11 中に矢印で示す。

杭頭荷重一杭頭変位関係の履歴特性には、小振幅領域から非線形 性が見られるが、振幅 $30 \mathrm{~mm}$ までは同一振幅で 2 サイクル繰り返 してもループはほぼ重なる。また、前章で示したように、振幅 $8 \mathrm{~mm}$ から杭周囲の地盤にすり鉢が形成されて杭の埋込が浅くなるが、㓮 性の急激な変化はなく、振幅の増加に伴ってループは、杭頭荷重の 最大值発現まで、原点を中心に相似形に拡大し、ループの中央が少 しくぼんだ紡鍾形を示す。

さらに振幅を大きくすると杭頭荷重は最大値に至る。杭頭荷重の 最大值（最大值に至った時の振幅）は $4 \mathrm{P} か ゙ ~ 40 \mathrm{kN}(60 \mathrm{~mm}) 、 9 \mathrm{P}$ が $75 \mathrm{kN}(45 \mathrm{~mm}) 、 4 \mathrm{P}-\mathrm{D}$ が $45 \mathrm{kN}(60 \mathrm{~mm}) 、 4 \mathrm{P}-\mathrm{L}$ が $27 \mathrm{kN}(60 \mathrm{~mm}) 、 4 \mathrm{P}-$ $\mathrm{X}$ が $38 \mathrm{kN}(90 \mathrm{~mm}) 、 4 \mathrm{P}-\mathrm{B}$ が $35 \mathrm{kN}(60 \mathrm{~mm})$ であった。ここで、い ずれの実験においても、杭頭荷重が最大值に至った際に、前方杭や 中間杭の杭頭モーメントは全塑性モーメントを超えていたが、後方
杭が全塑性モーメントに至ることはなかった。一例として、4P の 杭頭荷重が最大值に至った時の杭の曲げモーメント分布とそのとき の地盤変状を図 12 に示す。杭の曲げモーメント分布を見てもわか る様に、本実験の杭が Broms の算定式で定義される杭長さが「短 い杭か中間長さ杭」に分類されることを示している。杭頭付近は塑 性化していたので、鋼管の素材試験の結果を元に、弾性域でかつ地 盤に埋まっていない位置の歪(図 12 の矢印部分)を用いて、塑性 化した断面の曲げモーメントを算出した。そのとき、前方杭は全塑 性モーメントに達していたが、後方杭は全塑性モーメントに至って いなかった(図 12)。

一方、冨永らの模型実験 2)、青砥らの実大実験 3 )では、杭頭荷 重が最大值に至った後に、低下寸る傾向は見られなかった。しかし、 本実験においては、杭頭荷重は最大值に至った後、徐々に低下して おり、さらに変位 $100 \mathrm{~mm}$ 以上で一定値に収束している。ここで、 杭頭荷重が最大值に至った後、低下し始める付近で、前章に記述し た外周地盤に段差が現れている(写真 7、8)。

\section{5. 割線剛性と等価減衰定数}

杭 - 地盤系の非線形性を示す指標として、各振幅の杭頭最大変位 時の割線剛性と等価減衰定数について考察する。割線剛性と等価减 衰定数は正载荷と負載荷の平均值を用いる。図 13 に載荷荷重を各

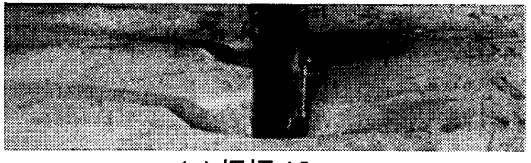

(a) 振幅 $12 \mathrm{~mm}$

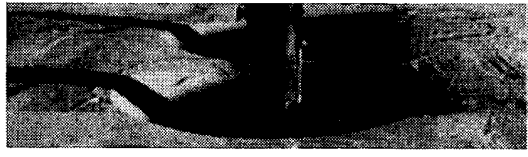

(b) 振幅 $24 \mathrm{~mm}$

写真 $12 \mathrm{P}$ の地盤变状

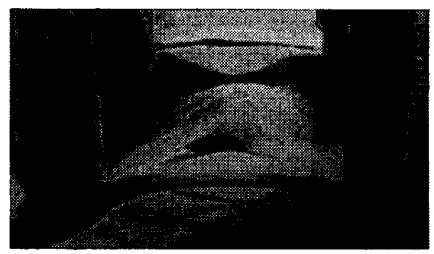

写真 4 杭間に現れた変状線 (4P, 振幅 $18 \mathrm{~mm})$

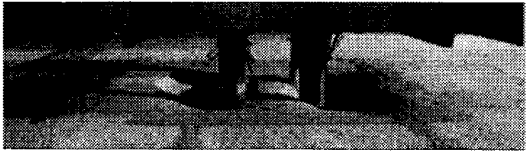

(a) 振幅 $12 \mathrm{~mm}$

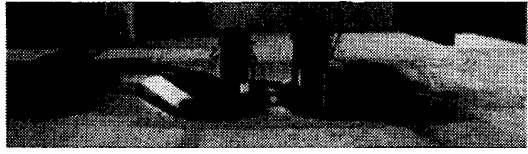

(b) 振幅 $24 \mathrm{~mm}$

写真 2 4P の地盤変状

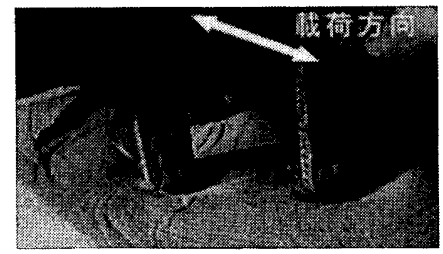

写真 5 4P-Xの地盤変状 (振幅 $18 \mathrm{~mm}$ )

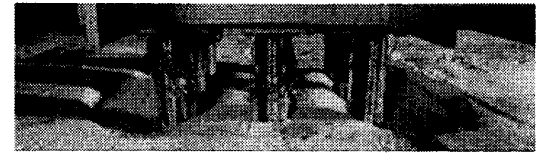

(a) 振幅 $12 \mathrm{~mm}$

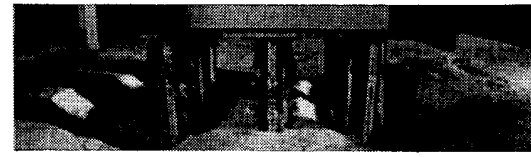

(b) 振幅 $24 \mathrm{~mm}$

写真 $39 P$ の地盤変状

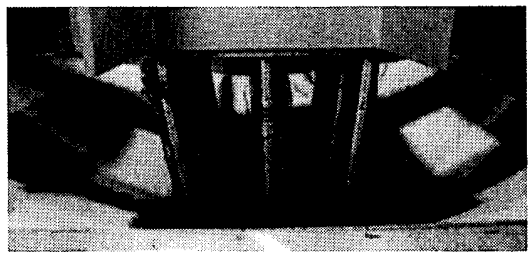

写真 $69 \mathrm{P}$ の地盤変状 (振幅 $180 \mathrm{~mm}$ )

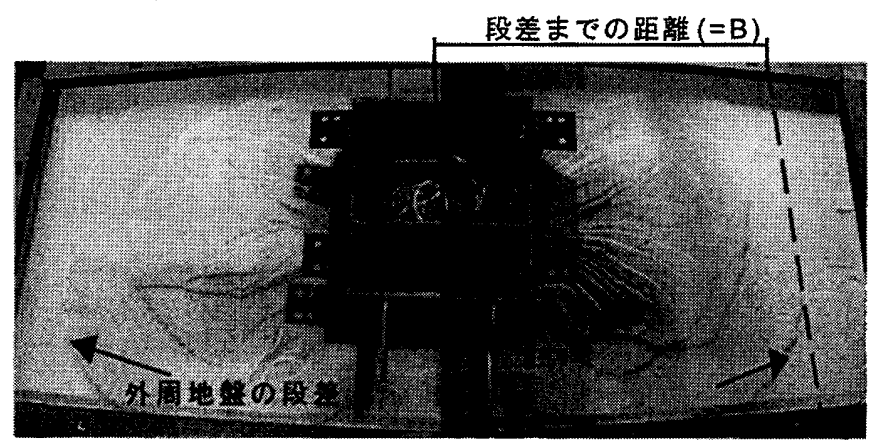

写真 $74 \mathrm{P}$ の外周地盤の地盤変状 (振幅 $180 \mathrm{~mm}$ )

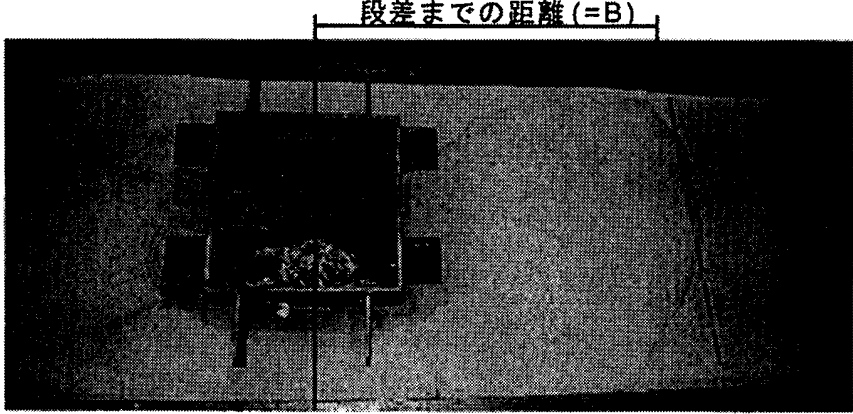

写真 8 4P-B の外周地盤の地盤変状（振幅 $180 \mathrm{~mm}$ ) 
実験の杭本数で除した 1 本あたりの平均杭頭せん断力 - 杭頭变位関 係と割線剛性の算出方法を示し、図 14 に等価減衰定数の算出方法 10)を示す。割線剛性、等価減衰定数の載荷振幅依存性を図 $15 、 16$ に示し、(a)杭本数、(b) 動的と静的、(c) 載荷方向、(d)相対密度に ついてそれぞれ比較する。

まず、割線剛性について、どの実験についても載荷振幅の増加に 伴つて減少する傾向がある。同一の載荷振幅で各実験を比較したと ころ、振幅 $60 \mathrm{~mm}$ までは、割線剛性は杭本数が少ないほど大きく (図 15(a))、相対密度が小さい4P-L の方が小さい(図 15(b))。それ らの差は振幅の増大に伴って徐々に减少し、振幅 $60 \mathrm{~mm}$ になると ほぼ等しくなる。載荷速度の速い 4P-D と載荷方向の異なる $4 \mathrm{P}-\mathrm{X}$ の割線剛性は、小振幅からほぼ 4P と同じであった(図 15(b)、(c))。 このように、杭 1 本あたりの平均でみると割線剛性は杭本数の違い、 相対密度による影響を受け、載荷速度や載荷方向による影響をほと んど受けない。しかし、振幅が増大すると最終的には載荷初期の約 $8 \%$ まで減少し、杭本数や相対密度による割線剛性の差も小さくな る。

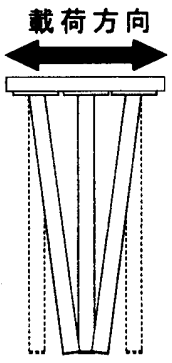

図 9 実験終了後の 杭の変形 $(9 P)$

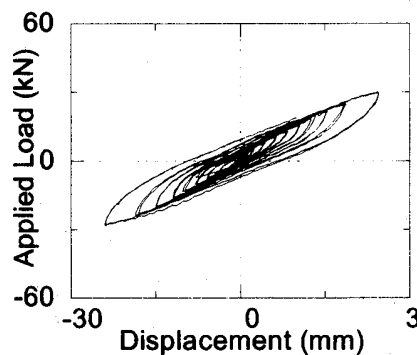

(b) $4 \mathrm{P}$

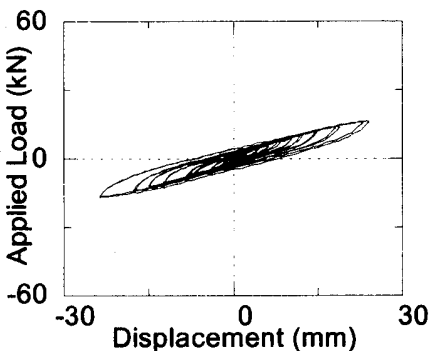

(a) $2 \mathrm{P}$

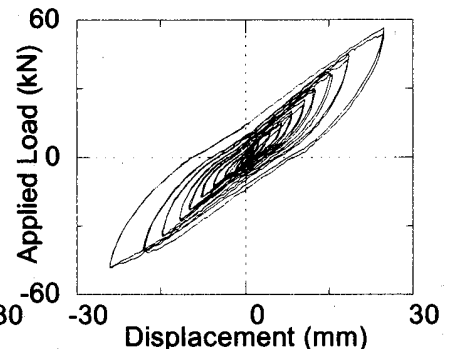

(c) $9 \mathrm{P}$
図 10 杭頭荷重 - 変位関係 (振幅 $24 \mathrm{~mm}$ まで)

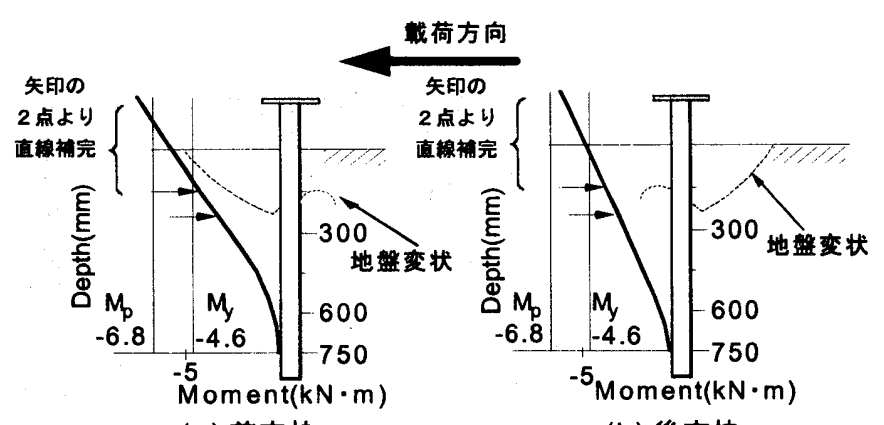

(a) 前方杭

(b) 後方杭

图 $124 P$ 最大耐力時の曲げモーメント分布
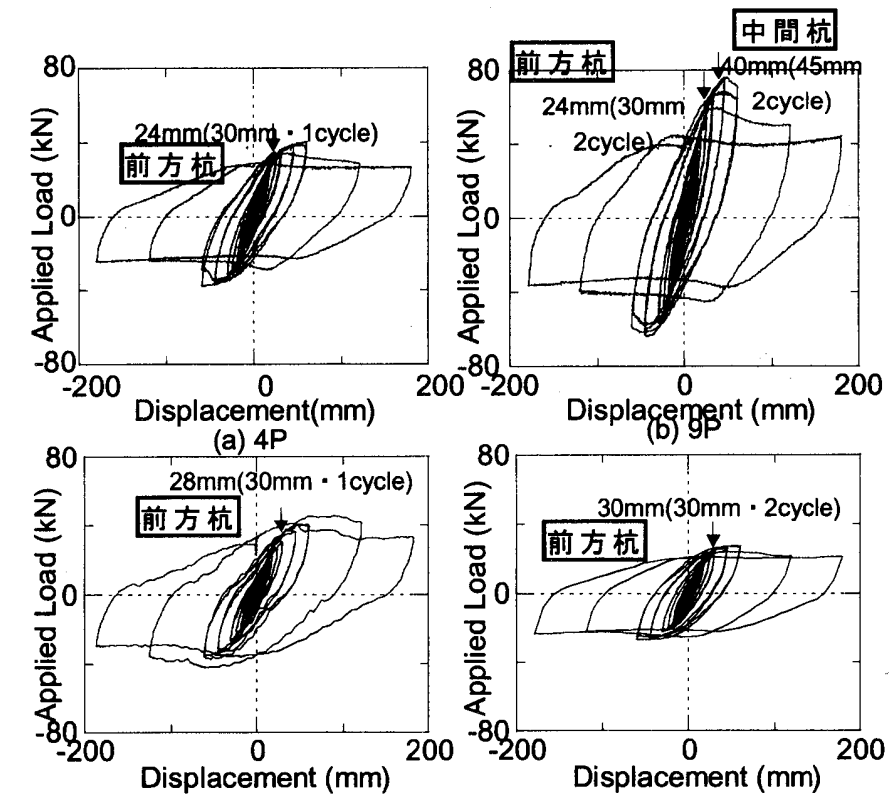

(c) 4P-D 中間杭
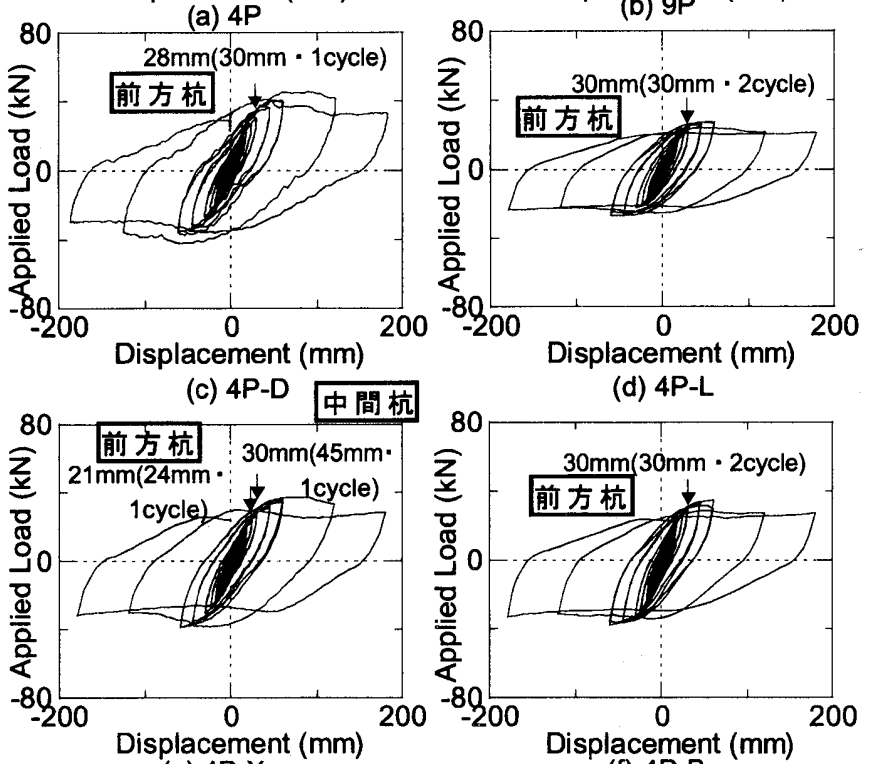

(e) $4 \mathrm{P}-\mathrm{X}$ (d) $4 \mathrm{P}-\mathrm{L}$

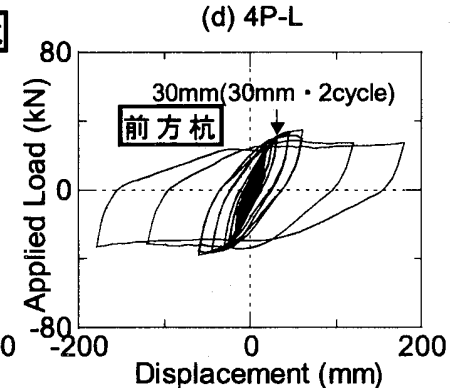

(f) $4 \mathrm{P}-\mathrm{B}$

図 11 杭頭荷重一杭頭变位関係 (振幅 $180 \mathrm{~mm}$ まで)

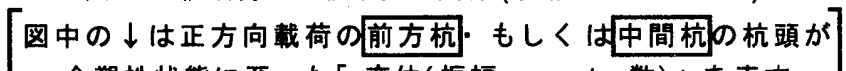
全塑性状態に至った「変位(振幅・cycle 数)」を表す

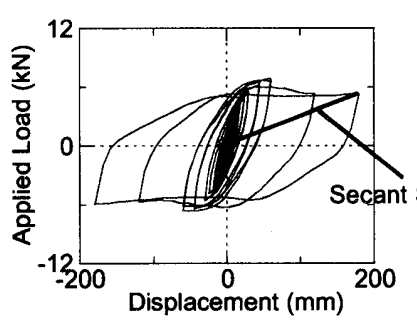

図 13 平均杭頭せん断力 杭頭变位関係 $(4 \mathrm{P})$

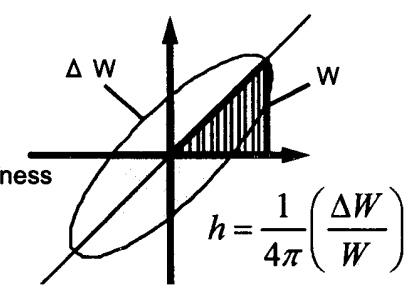

図 14 等価隇衰定数の 算出方法 


\section{6. 杭・地盤系の限界状態}

杭頭変位が $60 \mathrm{~mm}$ を超えると、写真 7、8 に示すような外周地盤 の段差が全ての実験において現れた。図 11 に示した杭頭荷重一杭 頭変位関保においても、杭頭荷重の最大值発現後に杭頭変位が $60 \mathrm{~mm}$ を超えて大きくなると、杭頭荷重が徐々に一定值に収束した。本論 文では、杭頭荷重が一定值に収束した原因を明らかにするために杭 頭の歪の挙動、杭頭最大変位時の杭の変位・土圧を調べた。以下で は杭に変位計を直接取り付けた $4 \mathrm{P}-\mathrm{X}$ の結果を用いて述べる。

振幅 $120 \mathrm{~mm}$ での履歴ループを図 17 に、正方向載荷時に前方に 位置する杭の地表面より $50 \mathrm{~mm}$ 下の断面の歪と杭頭変位との関係を 図 18 に示す。ここで、図 17、図 18 中のR1、R2 は、杭頭変位 $60 \mathrm{~mm}$ 以上の荷重が一定となる領域を示す。杭頭荷重が一定となる領域 R 1 、 R2 では、杭の歪は殆ど増加することなくほぼ一定値を保っている。 この傾向は全ての実験で共通しており、杭頭荷重が一定值に収束す るとき、杭頭変位が増加しても杭自身の変形は進行していないこと

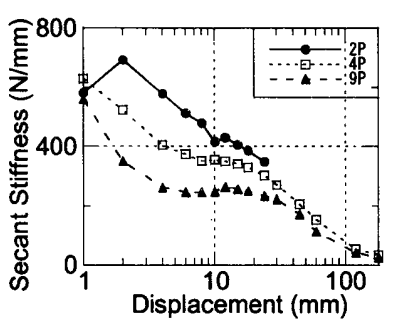

(a) 4P, 2P, and $9 \mathrm{P}$

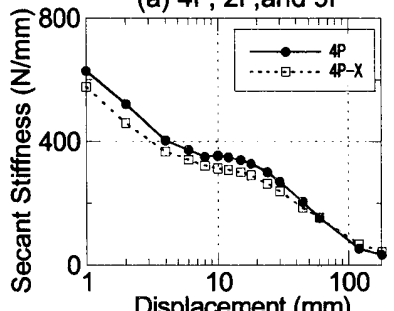

(c) $4 \mathrm{P}, 4 \mathrm{P}-\mathrm{X}$

图 15

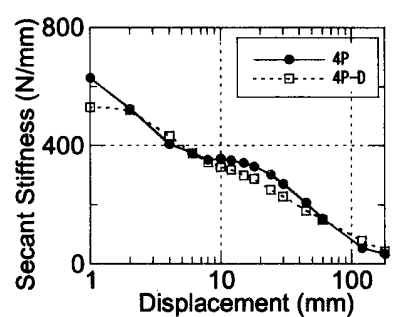

(b) 4P,4P-D

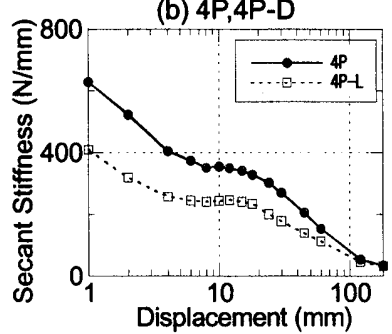

(d) 4P,4P-L

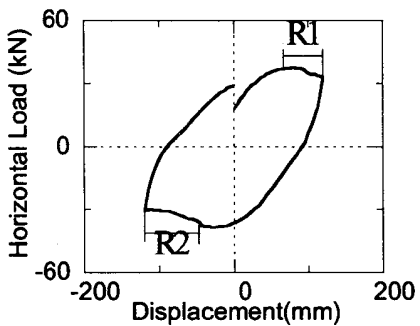

图 17 杭頭荷重 - 杭頭変位関係 (4P-X, 振幅 $120 \mathrm{~mm})$

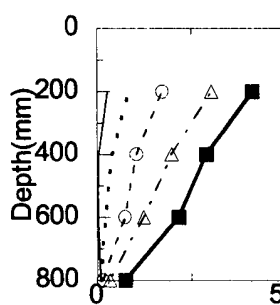

50

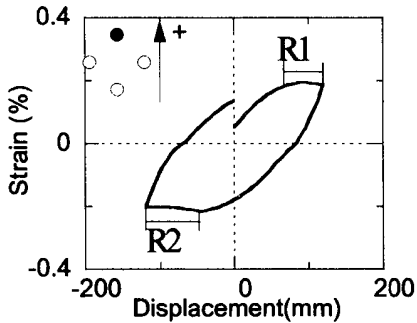

图 18 杭歪 - 杭頭変位関係 (4P-X-, GL -50mm)
図 19 各振幅の最大変位時での杭の変位 $(4 \mathrm{P}-\mathrm{X})$
が分かる。

また、代表的な載荷振幅における杭頭変位最大時の杭の変形を図 19 に、杭の土圧分布を図 20 に示す。まず、図 19 より杭頭変位が $60 \mathrm{~mm}$ までは杭のたわみは増大し続けるが、杭頭変位が $60 \mathrm{~mm}$ を 超えるとたわみは増加せずに、杭全体が㓮体的に変位している。す なわち、杭自身の変形は進行していないことが分かる。一方、図 20 より、杭頭変位が $60 \mathrm{~mm}$ を超えると、 $550 \mathrm{~mm}$ より浅い部分の杭に 作用する土圧が小さくなり、750 mm より哚い部分の土圧が大きく なる傾向が見られた。

以上より、杭頭荷重が最大値に至った後、徐々に低下して一定値 に収束している時、杭は地盤中を剛体変位し、550 $\mathrm{mm}$ より浅い地 盤の水平抵抗力が限界に達して破壊し、外周地盤に明瞭な段差を形 成したと考えられる。この時、杭と地盤の間では主に $750 \mathrm{~mm}$ より 樑い位置で応力が伝達されていると考えられる。

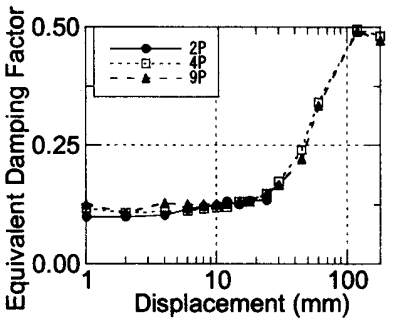

(a) 4P,2P,and 9P

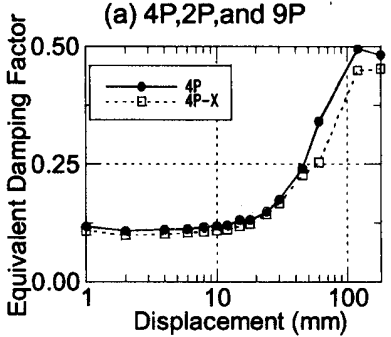

(c) $4 \mathrm{P}, 4 \mathrm{P}-\mathrm{X}$

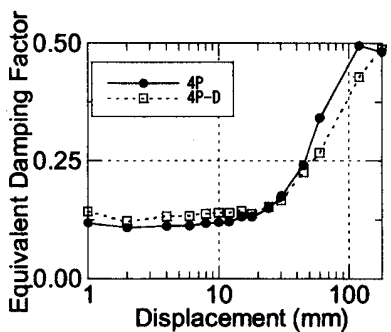

(b) 4P,4P-D

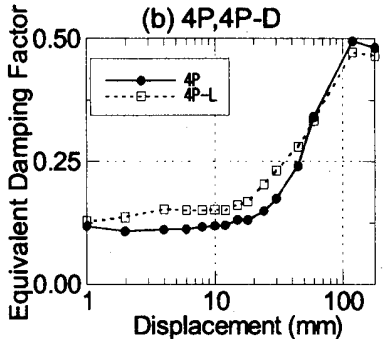

(d) 4P,4P-L

\section{図 16 等価減衰定数}

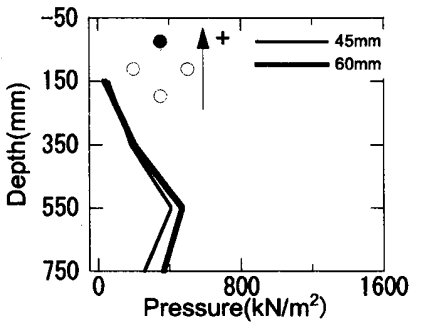

(a) 前方杭

(振幅 $45 \mathrm{~mm}, 60 \mathrm{~mm}$ )

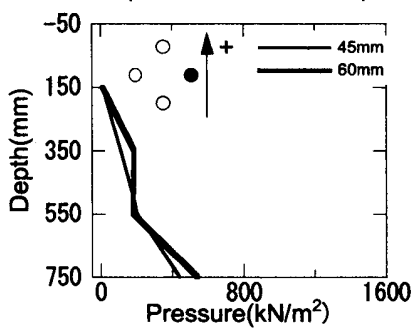

(c) 中間杭

(振幅 $45 \mathrm{~mm}, 60 \mathrm{~mm}$ )

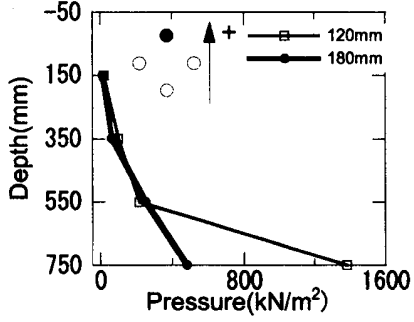

(b) 前方杭

(振幅 $120 \mathrm{~mm}, 180 \mathrm{~mm}$ )

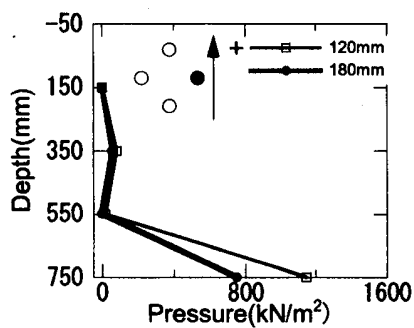

(d) 中間杭

(振幅 $120 \mathrm{~mm}, 180 \mathrm{~mm}$ )
図 20 各振幅の㵊大変位時での土圧 $(4 \mathrm{P}-\mathrm{X})$ 


\section{7. まとめ}

杭径を超える大振幅で、かつ載荷方向や載荷速度などの載荷条件 を変えて、乾燥砂地盤における単杭と群杭を模した実験の繰返水平 載荷実験を行った結果、以下の知見が得られた。ただし、本実験で の杭は Broms の算定式で定義される杭長さが「短い杭か中間長さ 杭」に分類される。

(1) 杭頭載荷によって、杭周囲地盤には明瞭なすり鉢状の変形やす べり線が生じた。生じたすり鉢の形状は、杭配置・地盤の相対 密度・載荷方向によって異なる。しかし、いずれの実験におい ても、杭頭変位が大きくなる $(60 \mathrm{~mm}$ 以上) と群杭全体を囲む 1 つの大きなすり鉢へと成長する一方、群杭から離れた外周地盤 表面に明瞭な段差が現れた。

(2) 載荷振幅の増大に伴って、杭頭荷重は最大値に至った後、徐々 に低下して一定値に収束した。杭頭荷重一变位関倸は、比較的 安定した紡鍾型の履歴特性を示し、地表に見られた地盤変状の 違いや実験条件による影響は小さかった。

(3) 平均杭頭せん断力 - 杭頭変位関係の割線剛性は、杭配置や地盤 の相対密度によって差があるが、振幅の増大に伴う割線剛性の 減少とともに、実験間の差も減少していく。一方、等価隇衰定 数は実験条件に大きく影響を受けず、振幅 $30 \mathrm{~mm}$ までほぼ一定 であるが、 $30 \mathrm{~mm}$ を超えると急增した。

(4) 杭頭荷重の最大值以降の低下や外周地盤表面に見られた明瞭な 段差は、地盤の水平抵抗力が限界に達して地盤が破壊したため であった。

\section{謝辞}

本研究は、科研費基盤研究(B)「耐震性能評価向上のための建 築物一の地震動入力低減機構解明に関する実証的研究（研究代表者 : 林康裕）」の一部として実施されました。

\section{参考文献}

1) 白方邦博, 中島寿, 竹澤請一郎, 上本秀之, 水野正之: 群杭の水平抵抗 と地盤の崩壊形状に関する模型実験（その1）, 土質工学研究発表会， E-4, pp.1601-1602, 1992.6

2) 畐永晃司, 山本晴行, 染川常二：鉛直力を受ける群杭の水平举動に関 する模型実験, 日本建築学会構造系論文集, No.394, pp.130-140, 1988.12

3) 青砥一浩, 富樫勝男, 尾形隆永, 佐藤立：龬管群杭の大変形水平載荷試 験とその数值シミュレーション, 第 46 回地盤工学シンポジウム, pp.229-pp234, 2001.11

4) Brown, D. A. , Morrison, C. , Reese, L. C. : Lateral Load Behavior of Pile Group in Sand, Journal of Geotechnical Engineering, ASCE, Vol.114, No.11, pp.1261$1276,1988.11$

5) 鈴木康嗣, 安達直人: 模型水平載荷試験による群杭の地盤反力〜变位 関保，日本建築学会構造系論文集，No.570,pp.115-122, 2003.8

6) 小林恒一, 八尾眞太郎：動的な水平載荷を受ける群杭基礎の挙動に関 する実験的研究, 日本建筑学会構造系論文報告集, No.425, pp.121-130, 1991.7

7) 中島勝弘, 大谷順, 帆足奈央: 動的水平荷重下における群杭効率の定量 的評価に関する模型実験, 土質工学研究発表会, D-6, pp.1769-1770, 2000.6

8) 富永晃司, 山有邦男：地盤の塑性状態を考虑した群杭の水平抵抗理論 一その 1 : 塑性地盤反力について一, 日本建築学会論文報告集, No.317, pp.32-39, 1982.7

9) 富永晃司，山有邦男：地盤の塑性状態を考虑した群杭の水平抵抗理論 一その 2 : 理論及び実験結果との比較検討一, 日本建築学会論文報告集 , No.321, pp.89-96, 1982.11

10) 日本建築学会：入門・建物と地盤との動的相互作用,pp.238-239, 1996 （2006年 7 月 3 日原稿受理，2006年12月 22 日採用決定） 